\title{
ДЖЕРЕЛА ОСОБОВОГО ПОХОДЖЕННЯ У ВИСВІТЛЕННІ СФЕРИ ПОВСЯКДЕННОСТІ ТА ЕМОЦИЙНИХ ПЕРЕЖИВАНЬ ЖІНОК ПІД ЧАС ПЕРШОЇ СВІТОВОЇ ВІЙНИ
}

Листи періоду Великої війни залишаються вагомим джерелом української історії ХХ ст. Перша світова поставила нові складні проблеми, загострила старі й рельєфно виявила слабкі місия суспільного буття. До иүієі вкрай важливої теми звертались у своїх дослідженнях О. Мельничук, Л. Варавко, Ю. Зінько, О. Кравчук, В. Косаківський, В. Рудь. Праці зазначених авторів стосуються саме чоловічого бачення Великої війни, щио дає підстави досліднику відтворити особливості епохи через відображення деталей побуту та реалій чоловічого повсякдення. У представленому дослідженні йдеться про неопубліковані жіночі листи до сотника Романа Сушка, котрі заперечують поширене припущення щуодо суто чоловічої природи війни. Історія жіночого досвіду та жіночих моделей пам'яті про війну відкривають нову сторінку контексту воєнних стратегій, а також гуманітарні, соціальні та ідеологічні виміри світового конфлікту 1914 - 1918 рр.

Ключові слова: епістолярій, І світова війна, УСС, гендерні ролі, Р. Сушко, С. Галечко, Г. Дмитерко.

Olha BEZHUK,

PhD (History), Associate Professor of Department of History of Ukraine and Economic Theory of S. Hzhytskyi Lviv National Veterinary and Biotech University (Lviv,Ukraine)omkostiv@ukr.net

\section{SOURCES OF PERSONAL ORIGIN IN COVERING THE SPHERE OF EVERYDAY LIFE AND EMOTIONAL EXPERIENCES OF WOMEN DURING THE WORLD WAR I}

The letters of the period of the Great World War remain a significant source of Ukrainian history of the $20^{\text {th }}$ century. World War I posed new challenges, aggravated old problems and in relief identified the disadvantages of social life. The epistolary significance of the mentioned period is reflected in the author's vision of the world's history and direct perception of the corresponding historical events and phenomena.

The tendency to understand the significance of the Great War, as its contemporaries called it, together with the desire to leave a reliable evidence of the tragic events for the future generations, have encouraged scholars to study memories, letters, and diaries in order to arrange the documents of that time. O. Melnychuk, L. Varavko, Y. Zin'ko, $O$. Kravchuk, V. Kosakivsky, and V. Rud'all addressed this extremely important topic in their researches. The works of the aforementioned authors precisely relate to the masculine vision of the Great War, which gives researchers an opportunity to recreate the features of the era more faithfully and fully through the reflection of details of everyday life and realities of the masculine lifestyle, to show and feel the way of life of the male society under the war conditions.

The presented study deals with the unpublished women's letters written to captain (sotnyk) Roman Sushko. They testify that the life of civilian women and their engagement in fighting became a severe test not only for the whole society, but also for the fair sex. Women viewed their participation in military operations as a patriotic duty and expansion of women's skills and practices, rather than as a violation of gender roles.

Shifting the emphasis on the history of women's war experience, studying women's models of memory of the war and state policy regarding women's front-line past, the analysis of the features of women's military psychology and women's behavior in the sources of personal origin has appeared to be the richest material to give a more complete picture of life and survival within the frames of the participants' evaluations and interpretations of the turbulent years of $1914-1918$.

Key words: epistolary testimony, World War I, UPA (Ukrainian Sich Riflemen), gender roles, R. Sushko, S. Halechko, H. Dmyterko. 
Ольга БЕЖУК,

кандидат исторических наук,

дочент кафедры истории Украины и экономической теории Львовского национального университета ветеринарной медицинь и биотехнологий имени С. 3. Гжицкого (Украина, Львов) omkostiv@ukr.net

\title{
ИСТОЧНИКИ ЛИЧНОГО ПРОИСХОЖДЕНИЯ В ОСВЕЩЕНИИ СФЕРЫ ПОВСЕДНЕВНОСТИ И ЭМОЦИОНАЛЬНЫХ ПЕРЕЖИВАНИЙ ЖЕНЩИН ВО ВРЕМЯ ПЕРВОЙ МИРОВОЙ ВОЙНЫ
}

\begin{abstract}
Письма периода Великой войны остаются важным источником украинской истории ХХ века. Первая мировая обнажила новые сложные проблемы, обострила старые и рельефно продемонстрировала слабые места общественного бытия. К этой крайне важной теме обращались в своих исследованиях А. Мельничук, Л. Варавко, Л. Зинько, О. Кравчук, В. Косакивский, В. Рудь. Работы указанных авторов касаются именно мужского видения Великой войны, дают основания исследователю воспроизвести особенности эпохи из-за отражения деталей быта и реалий мужской повседневности. В представленном исследовании пойдёт речь о неопубликованных женских письмах к сотнику Роману Сушко, которые отрицают распространенное предположение о сугубо мужской природе войны. История женского опыта и женских моделей памяти о войне открывают новую странииу в контексте военных стратегий, дают возможность увидеть шире гуманитарные, социальные, идеологические измерения мирового конфликта 1914 - 1918 гг.

Ключевые слова: епистолярий, Імировая война, УСС, гендерные роли, Р. Сушко, С. Галечко, Г. Дмитерко.
\end{abstract}

Постановка проблеми. Перша світова війна залишається однією з найбільших катастроф в історії людства, що залишила глибокий слід в пам'яті сучасників. Сьогодні особливо новими в українській історіографії $є$ «жіночі» сюжети історії Великої війни, що відкриваються дослідникам через джерела особового походження. Такого роду суб'єктивні документи стають особливо раритетними, адже мемуаристика як вид автобіографії, щоденники, листування помалу відходять у минуле XX століття, залишаючи нам безліч питань на ті чи інші судження-міркування, гіпотези їхніх авторок. Між тим, вивчення жіночих моделей пам'яті про війну та державної політики щодо жіночого фронтового минулого, аналіз особливостей жіночої військової психології та жіночої поведінки в тилу значно розширює систему історичних координат військового повсякдення, дає можливість більш повно осягнути всю складність і суперечливість індивідуального та групового досвіду теми «жінка і війна».

Аналіз досліджень. Зазначена проблематика не була предметом окремих наукових досліджень через брак джерел особового походження, особливо тих, що стосуються жіночих практик пристосування та виживання в часі Великої війни. Окремі повідомлення про жіночий досвід порушуються в наукових розвідках, присвячених періоду 1914 - 1918 рр. Йдеться, зокрема, про дослідження М. Богачевської-Хом'як (Богачевська-Хом'як, 1995), Б. Савчука (Савчук, 1998), Х. Овад (Овад, 2006), І. Вільде (Вільде, 2009). Зазначені автори вперше порушили питання активної ролі жінок як бійців на фронтах, мотиви вступу до армії, наслідки впливу війни на їхній подальший світогляд та життєву траєкторію.

Мета статті - через джерела особового походження (епістолярій) побачити ширше коло жінок, які безпосередньо чи опосередковано були причетні до війни, надати слово самим жінкам, котрі пережила військовий тотальний конфлікт 1914 - 1918 рр. Так чи інакше, специфіка листування полягає в їх індивідуальному, а отже неповторному баченні й трактуванні історичного фону, подій, явищ, атмосфери часу, чого не передає жодний офіційний документ, повідомлення в пресі чи інші комплексні дослідження. Якщо говорити про жіноче бачення дійсності, то воно вирізняється певною емоційністю, особливим шармом, настроєвими моментами, відвертими й сміливими зізнаннями на папері, який «усе стерпить». Мотиви поведінки жінок, їхні переживання, оцінки досвіду, наслідки в післявоєнний період є надзвичайно складними і цікавими. 
Врахувавши ці чинники, можна осягнути усе різноманіття, суперечливість й складність явища «жінка і війна».

Виклад основного матеріалу. Про те, що пам'ять має гендерне звучання, свідчить епістолярій «слабкої» статі періоду І світової війни до сотника Українських Січових Стрільців Романа Сушка. В листах, що містяться в особовому фонді відомого військовика, переважають саме жіночі послання, котрі різняться своїм баченням подій Великої війни та ії переосмисленням 1916 р. Спільним у трактуванні військового наративу є звичний повсякденний побут, що супроводжує дівчину/жінку, з його важливими деталями, настроями, переживаннями. Через них вимальовується соціальний статус авторок, освітній рівень, виховання, пріоритети й географія перебування в цей період. Серед них Олена (Галя) та Савина Козак - учительки з Ременова та Підлісок, їхня подруга Ольга, племінниця Меланка Сушко, львів'янки - Зоня Данкевич, Одарка Данилович, Орися Вітайко. На особливу увагу заслуговують листи-звернення до сотника січовичок Софії Галечко та Гандзі Дмитерко (ЦДІАУЛ. Ф. 353. Оп. 1. Спр. 205. Арк. 103 (95); Спр. 206. Арк. 114).

На той час Роман Сушко став безпосереднім учасником змагань за Маківку, про що писав історіограф стрілецтва Осип Думін. Пройшовши через Тухлю, Сколе, Камянку, в числі інших зупинив ворожий наступ поблизу Болехова, брав участь у боях за Семиківці на р. Стрипа. Василь Дзіковський -стрілецький літописець - так описував Романа Сушка: «Роман Сушко, найвірніша копія отамана Горука, трудящий, вічно зайнятий і холодний, але чемний і товариський, добрий товариш, а ще кращий сотник...Його холодний спокій впливав відрадою на хлопців $\mathrm{i}$ лагодив страшну дійсність знищення...» (Дзіковський, 1967: 238).

25 лютого 1916 р. Роман Сушко був представлений Корпусною Командою до державної нагороди, а 8 березня за розпорядженням Краєвої Оборони його нагороджено «Медаллю Хоробрості» («Allerhochste Belobende Anerkennung») (ЦДІАУЛ. Ф. 353. Оп. 1. Спр. 77. Арк. 135). Він, за визначенням В. Дзіковського, належав до тієї групи «новочасних лицарів, наче вроджених до меча, щоб воювати, людей, які в бою знаходять себе, своє живло, і які творять історію.... Це ті, які одним рухом, одним словом ведуть лави за собою і перемагають» (Дзіковський, 1967: 238). Та думається, що геройська тематика не була присутня в кореспонденції Р. Сушка (якою ми, на жаль, не володіємо). Адже початок Першої світової війни практично у всіх воюючих країнах зумовив запровадження жорсткої військової цензури з відповідними обмеженнями інформації та фотозйомок.

У листах до жінок/дівчат Роман Сушко доволі мало торкався подробиць нехитрого, скрашеного ним військового побуту, а деталі фронтових негараздів - пом'якшував. Натомість сотник ставить більше запитань до адресаток, щоб отримати оптимістичні відповіді: «Пишеш про впливи на війні. Вірю Тобі цілком, бо зі всіх сторін можна дізнатись про «життя» на війні. Безперечно впливи великі, недобрі, однако того не боюсь. Я знаю, що Ти хоч молодий, але сильний. Вірую також і в то, що благородна гарна душа може такою остатись як би там не було...» (ЦДІАУЛ. Ф. 353. Оп. 1. Спр. 205. Арк. 18). Дуже часто епістолярні опонентки закидують брак інформації у відповідях Р. Сушка на ті чи ті питання: «Ви мені кажете пишіть коротко...коротко не вмію, то Ви вже спеціаліст» (ЦДІАУЛ. Ф. 353. Оп. 1. Спр. 206. Арк. 7), «а що там у Вас чувати бо Ви нам, любі Вуйку, про себе ніколи нічого не хочите розказувати?» (ЦДІАУЛ. Ф. 353. Оп. 1. Спр. 205. Арк. 79).

Чому саме жінки становили більшість адресатів сотника УСС Р. Сушка? Думається, це було свідоме бажання людини на фронті щодо відновлення і повернення до стійкої традиційної структури цінностей, без якої вона втрачала відчуття власної національної ідентичності, «малої» батьківщини. Адже буденне безпечне життя, з його певними правилами, патріархальними традиціями й моральними цінностями, що підтримувалися релігійними переконаннями, - усе це, видавалося знищеним світовою війною та її непередбачуваними наслідками. Крім того, це було єдина нитка, що пов'язувала військовика із рідними, знайомими, близькими людьми, котрі могли відчути і зрозуміти, наскільки сильно війна змінила його - брата, коханого чи сина (Ремарк, 1988: 83). 
Інстинктивно розуміючи ці бажання адресата, рідні нечасто в посланнях згадують про воєнні наслідки, саме поняття війни і те, що вона несла часто опускається/уникається, або згадується побіжно. Складається враження, що навіть недалеко від фронту, життя йшло буденним темпом, де кожен робив мирну справу, забезпечуючи собі щоденне виживання. Так, Галя (Олена) Козак, добра приятелька/наречена Романа Сушка, чий епістолярій найбільш об'ємний, часто описує в листах свій повсякденний побут: «3 ранку до ночі - лекції у школі [...], потім хвильку газдую в кухни, а потім приходять дуже часто товаришки... Як гарна погода йдемо у трійку до ліса [...]. У лісі також збираємо квіти, я певна, що такі самі як Ти, а там читаємо, звичайно обговорюємо теми теперішньої війни...» (ЦДІАУЛ. Ф. 353. Оп. 1. Спр. 205. Арк. 89). В листі від 13.07.16 р. молода дівчина розповідає про свої вакації у Малих Грибовичах, описуючи місцеві красоти, де хочеться «злетіти високо понад всіх, далеко, Бог зна куди. Тут і про війну забуваєсь зовсім. Але ніколи не забуваємо про Вас...» (ЦДІАУЛ. Ф. 353. Оп. 1. Спр. 205. Арк. 92).

Львівська приятелька Зоня Данилович, надзвичайно юна, екзальтована молода дівчина пише з Перемишля: «Коли я так дивлюсь на збіжжя, в мені зроджується бажання вміти жати і любити то збіжжя і землю, так як ті, що все на ній роблять...» (ЦДІАУЛ. Ф. 353. Оп. 1. Спр. 205. Арк. 5). Лише Меланка Сушко, донька брата Василя, в листі від 09.08.16 р. просить вибачення, що нема змоги часто писати, «бо жнива, треба працювати у полі, бо хлопів нима... У нас вдома все по давньому [...]» ( ЦДІАУЛ. Ф. 353. Оп. 1. Спр. 205. Арк. 78-79 ).

Як видно, і під час війни поведінка жінок моделювалась за зразком патріархальної сім'ї: вона мала залишатися вдома, вести домашне господарство чи учителювати, виховувати, навчати дітей. Інколи в жіночому погляді на війну проступає наратив психологічного напруження, принесених страждань як невід’ємна ії складова: «Однак війна хибила у свої ціли, бо замість виробити в нас войовничого духа, противно настроїла нас дуже мирово і чоловік з тривогою глядить в будучність [...], з напруженням очікує, що нам хвиля принесе»,- пише Савина Козаківна в листі від 16.06.1916р. (ЦДІАУЛ. Ф. 353. Оп. 1. Спр. 206. Арк. 38). Інша адресатка - Ольга, розповідаючи про постійну самотність в чужому селі, підсумовує: « Впрочім все гаразд, тільки безнастанне напруження вичерпує усі сили...Будем лічити свої рани по війні, если щасливо її перебудемо» (ЦДІАУЛ. Ф. 353. Оп. 1. Спр. 206. Арк. 3). Як видно, війна так чи так зачіпала інтереси жіноцтва, вагомо впливала на їхню сферу буття, змінюючи чи руйнуючи його, завдаючи болю, втрат, змушуючи винаходити та використовувати певні стратегії виживання, пристосовуватися чи протидіяти ії руйнівному впливові.

3 листів видно, що неодноразово жінки порушують питання війни «у полі», їх цікавлять усі аспекти цілком «чоловічого» простору, від якого їх хочуть захистити/застерегти: «Романчику Любий! Як дуже люблю читати Твої листи і як дурна тішусь ними. Они такі поважні, серйозні і правдиві. Пишеш, «про події, які тут часом заходять не буду писати, бо они не цікаві для постороннього». Може бути, що справи у вашім важнім ремеслі для мене непотрібні і годі про них писати, але пам'ятай, що кажда справа є заразом справою нас всіх, бо ми як сам кажеш всі стрільці душею - вже займаємось тим докладно і всьо хочемо знати», - зазначає Галина Козаківна в листі від 09.05.16 р. (ЦДІАУЛ. Ф. 353. Оп. 1. Спр. 205. Арк. 21 ).

Цитата засвідчує, що І світова підштовхнула слабку стать до освоєння цілком нових, самостійних ролей, які розширили горизонти справжніх можливостей модерної жінки. Цьому сприяли відсутність певної політики та настанов влади - як австрійської, так й української - щодо жіноцтва, участь яких у громадсько-політичному житті була непропорційно малою. Звідси докори сумління у листах дівчат-учительок: «Ви живете там життям дуже трудним. Ми нічого не робимо, а занадто робимо дуже, дуже мало... Ми жінки, не буду говорити тут про жінок загалу, але учительки замалу участь беремо у загальнім світовім життю, а то під час війни. Певно виконувати свій положений обов язок совісно..., але то ще замало» (ЦДІАУЛ. Ф. 353. Оп. 1. Спр. 205. Арк. 7 зв., 10). «Маю до Вас ...справи з організації - маю питати Вас (не я сама) о пораду в дечім, нами щось властиво з Ванівною багато задумано» (ЦДІАУЛ. Ф. 353. Оп. 1. Спр. 205. Арк. 89). Про наміри послужити загальній справі пише й Одарка Данилович: «На мене находять часом ясні хвилі, тоді видається мені всьо до виконання і чую я вдоволення, та мало сих хвиль, а багато темних...» (ЦДІАУЛ. Ф. 353. Оп. 1. Спр. 205. Арк. 26) . 
Потреба в «кермуванні», «твердій руці», яка б спрямувала сили жіноцтва у правильному напрямку доволі часто проступає актуальним лейтмотивом у листах до Р. Сушка, котрий, на їхню думку, мав би їм підказати вихід з глухого кута бездіяльності: «Молоді учительки захоплюються всім. Они мають дуже гарні постанови у почуваннях до народу, але треба лиш руки старшої, твердішої, щоб нами уміло кермувала. Також та наша старшина, гуртуючи нас, не повинна соромити, а зрозуміти їі. Часом цілком інакше $є$ і то недобре впливає» ( ЦДІАУЛ. Ф. 353. Оп. 1. Спр. 205. Арк. 25). Як видно, війна стала тим каталізатором фемінізму, що змушував жінок діяти без чоловіків, розраховуючи лише на власні сили.

Це засвідчують цитати адресаток, котрі пишуть про власні сміливі кроки, як приклад нових емансипаційних змін у характері патріархальних галичанок. Дівчата різко виступають «проти ксьондзів, бо шкода на них часу», відкидають небажане заміжжя: «чого так дрожите? Страх які Ви. Таж нічого не кажу ідіть своїм твердим шляхом, - то Ви мене на нім не здибаєте. Ніколи не буду вимагати від Вас щось такого, що могло Вам справити прикрість. Обіцяю се Вам на будуче» (ЦДІАУЛ. Ф. 353. Оп. 1. Спр. 206. Арк. 12), або ж ініціюють його першими: «В виду загальної манії до женячки, і я теж в найближчім повоєннім часі думаю вженитися. Вже й вибрала собі товариша...хочу бачити зміни, хочу якось гарнійше уладити собі життя», - пише Ольга, товаришка Олени Козаківної (ЦДІАУЛ. Ф. 353. Оп. 1. Спр. 206. Арк. 3). Підсвідоме, не зовсім зрозуміле бажання радикальних змін було спробою втечі від споконвічних норм і правил, встановлених віками, котре так цінувалось чоловіками в умовах фронту, але вже не влаштовувало самих жінок. Розкол у свідомості щодо їхніх місій, прийнятних чи неприйнятних ролей у військовий час поклали найбільш рішучі українки-патріотки, вступивши до легіону УСС.

Вступ дівчат і жінок до армії на початку Великої війни стало найдраматичнішим експериментом усіх часів з підривом традиційних жіночих ролей (берегині, матері,) що перекреслював споконвічні поняття про жіночність здатну до насильства і смерті (Українські жінки, 2017: 80). Так, Олена Козаківна в одному з листів до Романа Сушка відкрито пишається землячками, котрі мали мужність відійти від нормативних гендерних ролей, незважаючи на скепсис та іронію чоловіків: «Так я «держу кріпко руку» з Тобою - стрільцьом, я подаю дружній привіт всім, а найбільше тим, як їх любиш називати загорілим, щзо не зважаючи ні на ніщо, роблять чесно своє. Кажу, що ми зовсім не далеко від Вас, лиш Ви (майорові) тримаєтесь «згорда» супроти нас. Не злюбилисьте жіноцтво будьто би оно не уміло б так добре воювати і же уважаєте посторонити. Пишу досить поважно, а не жартівливо» (ЦДІАУЛ. Ф. 353. Оп. 1. Спр. 205. Арк. 25).

Відомо, що в 1914 - 1915 рр. «свої» і «чужі» трактували Олену Степанів, Софію Галечко, Гандзю Дмитерко, Ярему Кузь як національних героїнь. Так, Ф. Мольнар - військовий кореспондент «Нової вільної газети», що виходила у Відні, 1915 р. писав: «Українські студенти відносяться до цих своїх дівчат-борців із зворушливою ніжністю. Вони в розмові з ними поважні і приятельські і навіть на момент не дають їм відчути, що вони є дівчатами» (Овад, 2006: 41). Та навесні 1916 р. австрійське командування видало наказ, яким заборонялося дівчатам і жінкам-військовослужбовцям перебувати на передовій й брати участь у боях. Про це зокрема згадується у листах до полковника Р. Сушка: «Пишеш, деякі пішли додому, а між ними тов. Галечко» - лист Олени Козак від 08.02.16 р. (ЦДІАУЛ. Ф. 353. Оп. 1. Спр. 205. Арк. 21-22), «Ви десь задоволені, що Галечко вже не в полі, в Вашій чоті, вона і Дмитерко перебувають у Відні...», - лист Орисі Вітайко з Відня від 10.06.16 р. (ЦДІАУЛ. Ф. 353. Оп. 1. Спр. 205. Арк. 85). Наказ про заборону несення бойової служби наніс величезний моральний удар жіноцтву, котре до цього прославило себе за межами Галичини і довело, що може нарівні, а інколи й краще за чоловіків справляти ратну справу. Роман Сушко, в сотні якого повнила службу С. Галечко, цінував жінок-січовичок і відкрито демонстрував прихильність до них. Відомо, що після конфузу який стався з С. Галечко перед приїздом австрійського генерала Блюма (хорунжа впала у глибоку яму на військових позиціях), сотник Р. Сушко особисто потиснув руку титулованій фронтовичці, давши незабутній урок стрільцям-гуцулам, котрі вперто не хотіли бачити себе «під бабою» (Липовецький, 2016: 2).

Демонстрація прихильності й захоплення жінками на фронті мала свої доленосні наслідки. Звідси - особисті листи-звернення Софії Галечко та Гандзі Дмитерко до Романа Сушка у пояс- 
ненні й перегляді подальшої участі їх в УСС. Остання 16.07.16 р. писала: «Тов. Галечко є ту в Коші, хотіли єї відіслати, але она робить різні старання щоби остатися. Ми були в Відні разом, она майже в тій справі, ту у нас ходить чутка, що всі дівчата знову мають піти.. Я взагалі не можу собі тепер представити чогось подібного. От краще не жити» (ЦДІАУЛ. Ф. 353. Оп. 1. Спр. 206. Арк. 14). Перебуваючи з травня 1916 р. в Кадрі - тиловій додатковій формації, що мала місце в австрійській армії, Г. Дмитерко відповідала за канцелярський відділ, а хорунжа С. Галечко «була без приділу.., через нові розпорядження і не дуже приязні» (ЦДІАУЛ. Ф. 353. Оп. 1. Спр. 206. Арк. 5). Це було тим більше парадоксально, що Софія Галечко була одна з небагатьох українок, удостоєна медалі Хоробрості II класу, чим дуже пишалася. Відомо, що чимало жінок, проявили вражаючу відвагу на фронті, проте лише одиниці визнавалися й нагороджувались командуванням, на відміну від чоловіків. Для Софії Галечко - вчорашньої студентки філософських студій, фахового керманича чоти, в часи тотального Брусилівського прориву просиджувати бездіяльно в тилу було справою абсурдною і геть неприйнятною. 27 червня 1916 р. вона пише до Р. Сушка: «Я в Кадрі. Справа моєї участі пішла до АОК. Маю повну надію, що вдасться мені вирватися звідси... розуміється своїми силами... На жаль поки що мушу сидіти тут і думати, думати як чесно поступили зі мною мої товариші і постаралися усунути мене. Як би ви знали як мені гірко, страшно гірко. За моїми хлопцями до яких так привикла» (ЦДІАУЛ. Ф. 353. Оп. 1. Спр. 205. Арк. 41-42). Будучи надзвичайно амбітною, цілеспрямованою, тендітна С. Галечко впродовж двох років доводила здатність фізично воювати за свою націю, переносити найважчі випробовування, брати відповідальність за життя «своїх хлопців», що засвідчують іiі щоденникові записи, зокрема «Третя чета» (Галечко, 1991: 11).

Якщо говорити про позицію Романа Сушка, то він став на сторону більшості фронтовиків, котрі підтримували січовичок, наголошували на жіночих чеснотах у війську, і одночасно заперечували конечну потребу у їхній присутності в подальших баталіях. Це приклад того, що у війську жінки стали об'єктами маніпуляцій з боку тих, хто контролює ці інституції: жіночі ролі у війську визначаються потребами війська, а не потребами жінок. Так, в одному з листів від 18.08.16 p. хорунжа С. Галечко гостро відповіла на нерозуміння сотником ії бажання залишитись у легіоні: «Сказала я тоді, що не мою до кого їхати і з чого жити. Знаю, що подумались те певно в тій хвилі, що стрілецтво се лише спосіб удержання для мене і ті ідеальні почування мої - се блефа. Скажу Вам лише, що тоді як йшла до стрільців мала місце в шпитали в Грацу і ціле удержання, себто разом яких 270 К, крім мешкання і харчу. Перед від’їздом заставила золотий годинник, 3 золоті перстені і літературу німецьку вартости 200 К. прочі всі золоті і срібні річи призначила на самопоміч УСС, як довідаєтесь колись з листів Малицької до мене (маю всі в Грацу). ... - все пишу тільки для пояснення, бо і не знаю навіть як заболіли мене Ваші слова» (ЦДІАУЛ. Ф. 353. Оп. 1. Спр. 206. Арк. 95).

Листи Г. Дмитерко та С. Галечко відображають не лише драматизм несприйняття загалом факту здатності жінок воювати, але й постійні шляхи подолання січовичками безпідставних закидів, викликів, потребу постійно доводити свою компетентність і бойову спроможність на фронті. Ці досягнення і перемоги в чоловічій сфері вимагали величезних фізичних та психічних жертв, напруження власних сил на межі можливостей: «Я би і так вижила і дала собі ради, якби не се, що на каждім кроці стрічають мене болючі закиди і тому хочу за всяку ціну лишитися до кінця стрільцем в поли... Не думаю писати за себе, подавати нові симпатичні події, сказались те, що плачу над собою, або махнули рукою» (ЦДІАУЛ. Ф. 353. Оп. 1. Спр. 206. Арк. 96, 109).

У листах чітко простежується психологічний та психічний рівень січовичок, їх безпосереднє несприйняття настанови поступитися місцем чоловікам, стійкість/слабкість щодо ворожого світу. Так, відповіді Г. Дмитерко засвідчують сильнішу психічну настанову, оптимізм й бажання жити попри все: «Ромку! Чи ти правду був так перенявся справою, чи лиш «випадало» так написати. Бо видиш я ще все таки вірю, що не всі люди злі. Ну але що до тебе, то я з давним респектом відношуся. Щодо життя, то я поступаю разом з ним. Деколи вперед, а часом мушу попроситися назад. Знаю, що мушу жити. Но зараз дуже богато камінів. Треба перескакувати, потоптати, а часом і копнути, щоби скорше дойти до означеного місця. Ми ще маємо пощо і нащо жити» (ЦДІАУЛ. Ф. 353. Оп. 1. Спр. 205. Арк. 64 ). 
Натомість С. Галечко, повністю виснажена, внутрішньо зруйнована зрадою, тих, кому віддано служила, на користь яких зробила вибір 1914 р., вступивши в легіон, писала: «Якби так хто дійсно любив мене і бажав мені щастя поміг би мені вправитися з тої клятої кадри в поле. Се було би дійсне милосердя. Сидіти тут в теплій хаті, далеко від бойової лінії тоді, коли инші поруч в обороні рідної землі - сидіти тут здоровому... чоловік дуріє прямо 3 болю. Всякі аргументи докази се лише пусті звуки... Знаю що згину, мушу згинути - лише болить мене, що може чужі люде будуть тоді зі мною» (ЦДІАУЛ. Ф. 353. Оп. 1. Спр. 206. Арк. 106).

Важка психологічна травма хорунжої далася взнаки наприкінці війни, коли в питанні несумісності жінок та військової служби державні мужі поставили остаточні крапки. Позбавлена участі на фронті, незрозуміла рідними, відкинута бойовими товаришами, С. Галечко свідомо «попала у вир і не виплила» під час купання у ріці Бистриця в червні 1918 р. (Дмитерко-Ратич, 1958: 5).

Висновки. Як видно, жіноцтво України в різний спосіб переживало війну і по-різному було залученим у збройні конфлікти. Іноді надзвичайні обставини відкривали жінкам нові нагоди і можливості для самореалізації та осягнення раніше недоступних ролей, спонукали до нестандартних рішень, вчинків, частіше змушували страждати фізично і психологічно, працювати на межі сил, зрідка війна перетворювала їх на героїнь. Так чи інакше, Велика війна призвела до зміни способу існування патріархального українського світу та суспільної свідомості загалом, зачепивши кожного окремого громадянина/громадянку. Однак майже до кінця XX ст. складний різноманітний і неоднозначний історичний досвід сегменту «жінка $\mathrm{i}$ війна» залишався поза увагою науковців, що пояснюється властивим історичній науці андроцентризмом. Крім того, подальший перебіг подій, страшні потрясіння і революційні зміни були настільки сильними, що затьмарили враження часів війни, а дійсність міфологізувалася уже під час війни.

Лише парадигматичні зміни в історичній науці, відомі як «антропологічний поворот» дали поштовх до систематичного вивчення і всебічного осмислення величезного спектру проблем, що охоплює ця тема. Грунтовний аналіз Великої війни через дослідження маловідомих або замовчуваних «жіночих» сторінок, розкриття ігнорованих аспектів $\epsilon$ певним внеском у переосмислення iї досвіду та можливість відкрити ширші гуманітарні, соціальні та ідеологічні виміри світового конфлікту $1914-1918$ pр.

\section{СПИСОК ВИКОРИСТАНИХ ДЖЕРЕЛ І ЛІТЕРАТУРИ}

Богачевська-Хом'як, 1995 - Богачевська-Хом'як М. Білим по білому: жінки в громадському житті України, 1884 - 1939. Київ: Либідь, 1995. 424 с.

Вільде, 2009 - Вільде І. Олена Степанів колись і тепер // Олена Степанів - Роман Дашкевич. Спогади і нариси / упоряд. Г. Сварник, А. Фелонюк. Львів, 2009. С. 97.

Галечко, 1991 - Галечко С. Третя чета // Літопис Червоної Калини, 1991. № 2. С. 10-11.

Дзіковський, 1967 - Дзіковський В. На Веселій - За Волю України. Нью-Йорк, 1967. 238 с.

Дмитерко-Ратич, 1958 - Дмитерко-Ратич Г. Із зброєю в руках (пам’яті Софії Галечко) // Наше життя. 1958. Листопад. С. 3-5.

Липовецький, 2016 - Липовецький С. Жінка в мундирі. [Електронний ресурс]. - Режим доступу https:// www.google.com/search?q $-8 \&$ oe=utf-8\&client=firefox-b-ab

Овад, 2006 - Овад Х. Полковник Роман Сушко (1894 - 1944). На вшанування його пам'яті. Торонто, 2006. $305 \mathrm{c}$.

Ремарк, 1988 - Ремарк Э.-М. На западном фронте без перемен. Возвращение: Романы: Пер. с нем. Москва: Художественная литература, 1988. 399 с.

Савчук, 1998 - Савчук Б. Жіноцтво в суспільному житті Західної України (остання третина XIX 1939 р.). Івано-Франківськ: Лілея-НВ, 1998. 280 с.

Українські жінки, 2017 - Українські жінки у горнилі модернізації. Під загальною редакцією О. Кісь. Харків: КСД, 2017. 303 с.

ЦДІАУЛ - Центральний державний історичний архів України у Львові. 


\section{REFERENCES}

Bohachevska-Khomiak, 1995 - Bohachevska-Khomiak M. Bilym po bilomu: zhinky v hromadskomu zhytti Ukrainy, 1884 -1939 [White on white: women in public life of Ukraine, 1884 - 1939]. Kyiv: Lybid, 1995.424 s. [in Ukrainian].

Vilde, 1998 - Vilde I. Olena Stepaniv kolys i teper [Olena Stepaniv once and now] // Olena Stepaniv - Roman Dashkevych. Spohady i narysy / uporiad. H. Svarnyk, A. Feloniuk. Lviv, 2009. S. 97. [in Ukrainian].

Halechko, 1991 - Halechko S. Tretia cheta [The third chata] // Litopys Chervonoi Kalyny, 1991. № 2. S. 10-11. [in Ukrainian].

Dzikovskyi, 1967 - Dzikovskyi V. Na Veselii [On Veselij] // For the Will of Ukraine. New York, 1967. 238 s. [in Ukrainian].

Dmyterko-Ratych, 1958 - Dmyterko-Ratych H. Iz zbroieiu v rukakh (pam'iati Sofii Halechko) [With arms in his hands (in memory of Sofia Galechko] // Our life, 1958. November. S. 3-5. [in Ukrainian]

Lypovetskyi, 2016 - Lypovetskyi S. Zhinka v mundyri [Woman in uniform] // Retrieved from: https://www. google.com/search?q-8\&oe=utf-8\&client=firefox-b-ab [in Ukrainian].

Ovad, 2006 - Ovad X. Polkovnyk Roman Sushko (1894 - 1944). Na vshanuvannia yoho pam'iati [Colonel Roman Sushko (1894 - 1944). In honor of his memory]. Toronto, 2006. 305 s. [in Ukrainian].

Remark, 1988 - Remark Э-M. Na zapadnom fronte bez peremen. Vozvrashchenye: Romanы [On the western front without change. Return: Novels: Per. with him]. Moscow: Fiction, 1988. 399 s. [in Russian].

Savchuk, 1998 - Savchuk B. Zhinotstvo v suspilnomu zhytti Zakhidnoi Ukrainy (ostannia tretyna XIX - 1939 r.) [Savchuk B. Women in the social life of Western Ukraine (the last third of the nineteenth - 1939)]. Ivano-Frankivsk: Lileia-NV, 1998. 280 s. [in Ukrainian].

Ukrainski zhinky, 2017 - Ukrainski zhinky u hornyli modernizatsii. Pid zahalnoiu redaktsiieiu O. Kis [Ukrainian women in the modernization chimney. Under the general editorship of O. Kis]. Kharkiv: KSD, 2017. 303 s. [in Ukrainian].

TsDIAUL - Tsentralnyi derzhavnyi istorychnyi arkhiv Ukrainy u Lvovi [Central State Historical Archive of Ukraine in Lviv].

Стаття надійшла до редакиії 8.02.2018 p. 